\title{
Technological Aspects of Vegetable Oils Transesterification with Ethanol in the Presence of Metal Oxides
}

\author{
Y. Melnyk, ${ }^{*}$ R. Starchevskyi, and S. Melnyk \\ Department of Organic Products Technology, Lviv Polytechnic National University \\ S. Bandery str., 12, Lviv, Ukraine, 79013
}

\begin{abstract}
Transesterification of vegetable oil with ethanol in the presence of fine metal oxide particles as catalysts has been investigated. Zinc and nickel(II) oxides were shown to have the highest catalytic activity. In their presence, the conversion of sunflower oil triglycerides, after $150 \mathrm{~min}$, reached 95.3 and $94.2 \%$, respectively. The optimal mass fraction of zinc oxide catalyst was found to be $0.25-0.31 \%$. In the presence of zinc oxide, with mass fraction of water in ethanol of 5 and $10 \%$, the conversion of triglycerides was 98.5 and $94.8 \%$, respectively.
\end{abstract}

\section{Keywords}

Transesterification, triglycerides, metal oxides, ethanol

\section{Introduction}

The main catalysts for the transesterification of vegetable oils triglycerides with lower alcohols are the basic compounds - hydroxides and sodium or potassium alcoholates. ${ }^{1}$

Heterogeneous catalysts, unlike homogeneous catalysts, can be easily separated from the reaction mixture and used many times. Moreover, when using heterogeneous catalysts, it is easier to realize a continuous process. ${ }^{2,3}$ That is why a great number of investigations today focus on heterogeneous transesterification catalysts.

One of the applications of heterogeneous catalysts is the heterogenization of conventional homogeneous catalysts on a carrier. Ilgen and Akin showed the possibility of using aluminium oxide coated with $\mathrm{NaOH}, \mathrm{LiOH}, \mathrm{KOH}$, $\mathrm{Na}_{2} \mathrm{CO}_{3}, \mathrm{~K}_{2} \mathrm{CO}_{3}$ for transesterification of canola oil with methanol. ${ }^{4} \mathrm{KOH} / \gamma-\mathrm{Al}_{2} \mathrm{O}_{3}$ was found to be the best catalyst allowing a fatty acid methyl esters yield of $82.29 \%$ after $9 \mathrm{~h}$.

Silicon oxide has been proposed as a carrier for the $\mathrm{K}_{2} \mathrm{CO}_{3}$ catalyst. ${ }^{5}$ This catalyst was investigated in the transesterification reaction of palm oil with methanol. In such a case, the yield of fatty acid methyl esters was $98.10 \%$.

$\mathrm{KOH} / \mathrm{Ca}_{12} \mathrm{Al}_{14} \mathrm{O}_{33}$ was proposed as a catalyst for the transesterification of canola oil with methanol. ${ }^{6}$ The determined conditions were: alcohol : oil molar ratio of $12: 1$, a reaction time of $60 \mathrm{~min}$, and a catalyst mass fraction of $4 \%$. The reaction mixture was heated by microwave radiation. Under these conditions, the authors achieved a triglyceride conversion of $83.5 \%$. It is proposed to regenerate the catalyst by annealing at $700{ }^{\circ} \mathrm{C}$.

${ }^{*}$ Corresponding author: Yurii Melnyk, PhD

Email:yurii.r.melnyk@lpnu.ua
As catalysts, the use of lithium, sodium or potassium nitrates supported on calcium and magnesium oxides ${ }^{7}$ is also proposed. The highest conversion of rapeseed oil triglycerides transesterified with methanol was provided by the catalysts consisting of lithium nitrate supported on calcined calcium and magnesium oxides. MacLeod et al. have shown that the basicity of the most active catalysts is in the range of $\mathrm{pH} 11-15 .^{7}$ The decrease in $\mathrm{pH}$ value below 11 sharply decreased the catalyst activity, and the triglycerides conversion was 3-8 \%.

Alkaline earth oxides are also proposed as transesterification catalysts. Calcium oxide was proposed as a catalyst for transesterification of crude Salvadora alii oil and Thespesia populneoides oil with methanol. ${ }^{8}$ The mentioned catalyst allowed a $90 \%$ yield of fatty acids methyl esters at $65{ }^{\circ} \mathrm{C}$, methanol : oil molar ratio of (6-10): 1 and catalyst mass fraction of $3-3.5 \%$. To intensify the process, ultrasonic radiation was used.

Martinez-Guerra and Gude investigated the transesterification of used vegetable oil with methanol in the presence of barium oxide. ${ }^{9}$ The yield of fatty acid methyl esters was found to be $93.5 \%$ at alcohol : oil ratio of $6: 1$, catalyst mass fraction of $0.75 \%$, and combined treatment with ultrasonic waves and microwave radiation with a total power of 200 watts.

Xiang et al. studied the catalytic transesterification of waste cooking oil with methanol in the presence of ultrasonic radiation. ${ }^{10}$ It was found that at alcohol : oil molar ratio of 10.71 : 1 and modified coal ash mass fraction of $4.97 \%$, the yield of methyl esters reached $95.57 \%$. The catalyst was modified via hydrothermal treatment in the presence of potassium hydroxide.

Anion exchange resin Amberlyst A26 OH was investigated as heterogeneous catalyst of tallow fat methanolisys. The 
result of this investigation was a biodiesel yield of 90-95\% after 360 min. $^{11}$

Melnyk et al. demonstrated the possibility of using CU-2-8 cation exchange resin with immobilized metal ions as catalysts for transesterification of vegetable oils. ${ }^{12}$ Under the optimal conditions, in the presence of the best catalysts, when using ethanol, the triglycerides conversion was more than $99 \%$, and when propan-1-ol was used, the conversion exceeded $97 \%$.

The use of metal oxides as heterogeneous catalysts for transesterification of sunflower oil with butan-1-ol has been investigated by Melnyk et al. ${ }^{13}$ In order to intensify the process, the authors investigated the transesterification of sunflower oil triglycerides in the presence of ultrasonic waves. Zinc and nickel(II) oxides as catalysts achieved a conversion of triglycerides above $97 \%$ at a molar ratio of butan-1-ol:triglyceride equal to $15: 1$, and almost complete conversion of triglycerides at the molar ratio of $20: 1$ after $150 \mathrm{~min}$.

The above data indicate the effectiveness of heterogeneous transesterification catalysts. However, the amount of metal oxides studied in this process is quite limited. Therefore, the aim of this research was to investigate the technological aspects of using a fairly wide range of metal oxides in the transesterification reaction of vegetable oils with ethanol.

\section{Experimental}

\subsection{Materials}

Sunflower (refined, DSTU 4492:2005), rapeseed (coldpressed, DSTU 8175:2015) and linseed (refined, DSTU ISO 150-2002) oils were used as fatty raw material and triglyceride sources. Analytical grade ethanol was used. Fine powders of the metal oxides $\mathrm{ZnO}, \mathrm{NiO}, \mathrm{MgO}, \mathrm{SnO}_{2}$, $\mathrm{MnO}, \mathrm{PbO}, \mathrm{Al}_{2} \mathrm{O}_{3}, \mathrm{Cr}_{2} \mathrm{O}_{3}$ (all of analytical grade) were used as catalysts.

\subsection{Experimental procedure}

Transesterification of sunflower oil triglycerides (TG) was carried out with anhydrous ethanol at $75{ }^{\circ} \mathrm{C}$ and ethanol : TG molar ratio of $(3.6-5.7)$ : 1 . The amounts of triglycerides were recalculated relative to glycerol trioleate. The mass fraction of catalyst was $0.25 \%$. The effect of the catalyst mass fraction was studied using zinc oxide. Its mass fraction in the reaction mixture varied in the range from 0.13 to $0.50 \%$. The transesterification reaction was carried out during $150 \mathrm{~min}$.

The transesterification reaction was carried out in a glass three-necked reactor equipped with a reflux condenser under stirring. The samples were taken every $30 \mathrm{~min}$. The ethanol content was determined by chromatography, the acid number - by titrimetry after 150 min of the reaction.

Ultrasound was used for transesterification of sunflower oil with ethanol in the presence of zinc oxide. The mass fraction of water in ethanol was 5 and $10 \%$. To study the effect of ultrasonic waves on the transesterification reaction, the reaction mixture was treated in the reactor using a UZDN-2T ultrasonic disperser throughout the reaction time. Nominal ultrasonic power was $400 \mathrm{~W}$, and oscillation frequency was $22 \mathrm{kHz}$.

\subsection{Physicochemical analysis}

Chromatographic analysis of the reaction mixture was performed using a gas-liquid chromatograph LHM-80 with a thermal conductivity detector under the following conditions: column with diameter of $3 \mathrm{~mm}$, and length of $2000 \mathrm{~mm}$ filled with $5 \%$ Silicone SE30 on a Chromaton $\mathrm{N}-\mathrm{AW}$; carrier gas was helium with a volume flow rate of $3.0 \mathrm{Ih}^{-1}$; the temperatures of column thermostat, detector, and evaporator were $120^{\circ} \mathrm{C}, 220^{\circ} \mathrm{C}$, and $230{ }^{\circ} \mathrm{C}$, respectively; current strength on the detector was $140 \mathrm{~mA}$; sample volume was $2 \mu \mathrm{l} .{ }^{14}$ The acid number was determined by alkalimetric titration. ${ }^{15}$

\subsection{Data analysis}

Chromatographic analysis was used to determine the ethanol content in the reaction mixture. In accordance with the values of ethanol concentration at the initial and current times, the ethanol conversion, and then the conversion of triglyceride regarding the glycerol trioleate were calculated.

The initial and final values of the acid number of the reaction mixture were used to calculate the conversion of acid groups present in the free fatty acids (FFA) of oils. The initial rate of transesterification reaction was calculated as the ratio of the modulus of the difference in triglyceride concentration at the current and initial time to the time interval. The initial rate was calculated after 30 min of reaction.

\section{Results and discussion}

\subsection{Effect of metal oxide}

Melnyk et al. found that among zinc, nickel(II), iron(II), copper(II), and cobalt (II, III), as well as cobalt(III) oxides, such as $\mathrm{ZnO}$ and $\mathrm{NiO}$, exhibit the highest activity in the transesterification reaction of sunflower oil triglycerides with ethanol. ${ }^{14}$ However, they investigated a rather limited range of metal oxides under restricted conditions of the transesterification process.

The results of transesterification of sunflower oil triglycerides with ethanol in the presence of zinc, nickel(II), magnesium, tin(IV), manganese(II), lead(II), aluminium, and chromium(III) oxides show a correlation between the initial reaction rate and triglyceride conversion achieved after $150 \mathrm{~min}$ (Table 1). None of the studied oxides was found to provide triglyceride conversion comparable with the most active zinc and nickel(II) oxides. Manganese(II), magnesium, and tin(IV) oxides also exhibit high activity in the transesterification reaction. However, in their presence, the conversion of triglycerides failed to exceed $87-88 \%$ after $150 \mathrm{~min}$. 
The oxides of aluminium, chromium(III), and lead(II) showed the lowest activity. The initial transesterification rate of sunflower oil triglycerides in their presence was in the range of $(2.09-2.44) \cdot 10^{-4} \mathrm{~mol} /(\mathrm{L} \times \mathrm{s})$, i.e., $1.5-1.8$ times lower than that in the presence of zinc oxide, and 1.3-1.5 times lower than with nickel(II) oxide. The conversion of sunflower oil triglycerides per 150 min of reaction in the presence of $\mathrm{Al}_{2} \mathrm{O}_{3}, \mathrm{Cr}_{2} \mathrm{O}_{3}$ and $\mathrm{PbO}$ was only $67.4-73.1 \%$.

Table 1 - Indicators of sunflower oil triglycerides transesterification with ethanol in the presence of metal oxides. (Temperature $75{ }^{\circ} \mathrm{C}$, catalyst content $0.25 \mathrm{wt} \%$, molar ratio ethanol: TG $3.8: 1$ )

\begin{tabular}{c|c|c|c}
\hline \multirow{2}{*}{ Catalyst } & \multicolumn{2}{|c|}{ TG conversion $\%$} & $\begin{array}{c}\text { Initial reaction rate } \\
r \times 10^{4}, \mathrm{~mol} /(\mathrm{L} \times \mathrm{s})\end{array}$ \\
\cline { 2 - 3 } & $30 \mathrm{~min}$ & $150 \mathrm{~min}$ & 3.75 \\
\hline $\mathrm{ZnO}$ & 76.7 & 95.3 & 3.16 \\
\hline $\mathrm{NiO}$ & 64.7 & 94.2 & 3.45 \\
\hline $\mathrm{MnO}$ & 70.7 & 86.9 & 2.31 \\
\hline $\mathrm{Al}_{2} \mathrm{O}_{3}$ & 47.4 & 70.0 & 2.09 \\
\hline $\mathrm{Cr}_{2} \mathrm{O}_{3}$ & 42.8 & 67.4 & 3.58 \\
\hline $\mathrm{SnO}_{2}$ & 73.3 & 88.2 & 3.93 \\
\hline $\mathrm{MgO}$ & 80.4 & 94.0 & 2.44 \\
\hline $\mathrm{PbO}$ & 50.0 & 73.1 & \\
\hline
\end{tabular}

We can represent the following activity ranges of the investigated metal oxides:

according to the initial reaction rate

$$
\begin{aligned}
\mathrm{MgO} & >\mathrm{ZnO}>\mathrm{SnO}_{2} \approx \mathrm{MnO}>\mathrm{NiO} \gg \mathrm{FeO}>\mathrm{PbO} \approx \\
& \approx \mathrm{Al}_{2} \mathrm{O}_{3}>\mathrm{CuO}>\mathrm{Co}_{3} \mathrm{O}_{4} \approx \mathrm{Cr}_{2} \mathrm{O}_{3}>\mathrm{Co}_{2} \mathrm{O}_{3}
\end{aligned}
$$

according to the triglycerides conversion achieved after $150 \mathrm{~min}$

$$
\begin{aligned}
\mathrm{ZnO} \approx \mathrm{NiO} & \approx \mathrm{MgO}>\mathrm{SnO}_{2} \approx \mathrm{MnO}>\mathrm{FeO}>\mathrm{CuO} \approx \\
& \approx \mathrm{PbO}>\mathrm{Al}_{2} \mathrm{O}_{3} \approx \mathrm{Cr}_{2} \mathrm{O}_{3}>\mathrm{Co}_{2} \mathrm{O}_{3}
\end{aligned}
$$

\subsection{Effect of process technological parameters}

The effect of the ethanol: TG molar ratio on the transesterification of sunflower oil triglycerides was investigated using zinc oxide as the catalyst. With the increase in alcohol content, both the initial conversion of triglycerides and their conversion after 150 min increased monotonically. Moreover, at the molar ratio of $3.6: 1$, the triglycerides conversion after 150 min was almost $98 \%$ and increased by only $1 \%$ with a further increase in the molar ratio to $5.7: 1$ (Fig. 1).

The increase in ethanol : TG molar ratio had a more significant effect on the initial conversion of triglycerides: from $81.2 \%$ (at $4.1: 1$ ) to $85.0 \%$ (at $5.7: 1$ ) after $30 \mathrm{~min}$. Such results were expected, since the increase in the molar ratio, and therefore the ethanol concentration in the reaction mixture, caused the increase in the transesterification rate in the initial period (Table 2). The increase in the molar

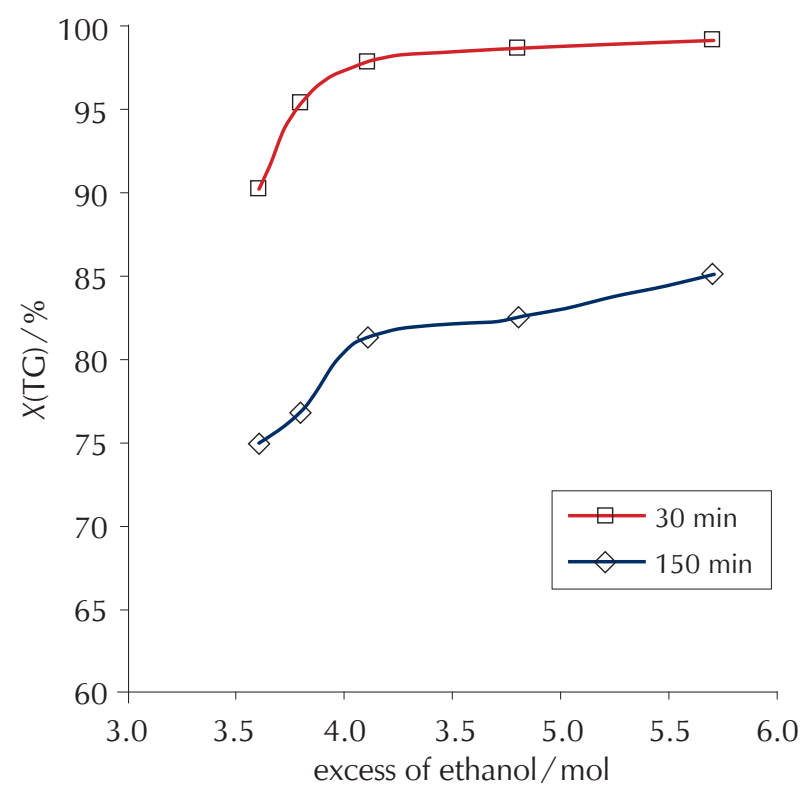

Fig. 1 - Dependence of TG conversion on the molar excess of ethanol in the transesterification reaction of sunflower oil. (Zinc oxide catalyst, catalyst mass fraction $0.25 \%$, temperature $75^{\circ} \mathrm{C}$ ).

excess of more than $4.1: 1$ led to no further increase in the conversion of triglycerides (Fig. 1).

Table 2 - Effect of ethanol : triglycerides molar ratio on initial transesterification rate of sunflower oil triglycerides. (Temperature $75{ }^{\circ} \mathrm{C}$, zinc oxide catalyst, catalyst mass fraction $0.25 \%$ )

Ethanol : TG molar ratio Initial reaction rate $/ r \times 10^{4}, \mathrm{~mol} /(\mathrm{L} \times \mathrm{s})$

\begin{tabular}{l|l}
\hline $3.6: 1$ & 3.70 \\
\hline $3.8: 1$ & 3.75 \\
\hline $4.1: 1$ & 3.92 \\
\hline $4.8: 1$ & 3.84 \\
\hline $5.7: 1$ & 3.78 \\
\hline
\end{tabular}

Melnyk et al. found that, during transesterification of sunflower oil triglycerides with butan-1-ol in the presence of metal oxides, an extreme dependence of TG conversion on the catalyst concentration was observed..$^{13}$

Similar results were obtained for the transesterification of sunflower oil triglycerides with ethanol in the presence of zinc oxide (Fig. 2). It was established that within the catalyst mass fraction of $0.13-0.50 \%$, there was an extreme dependence of both the initial conversion of triglycerides and their conversion after $150 \mathrm{~min}$.

An evident extremum of triglycerides conversion after 30 min was observed for catalyst mass fraction of $0.25 \%$. The maximum triglycerides conversion after 150 min was achieved with the mass fraction of zinc oxide $0.25-0.31 \%$. 


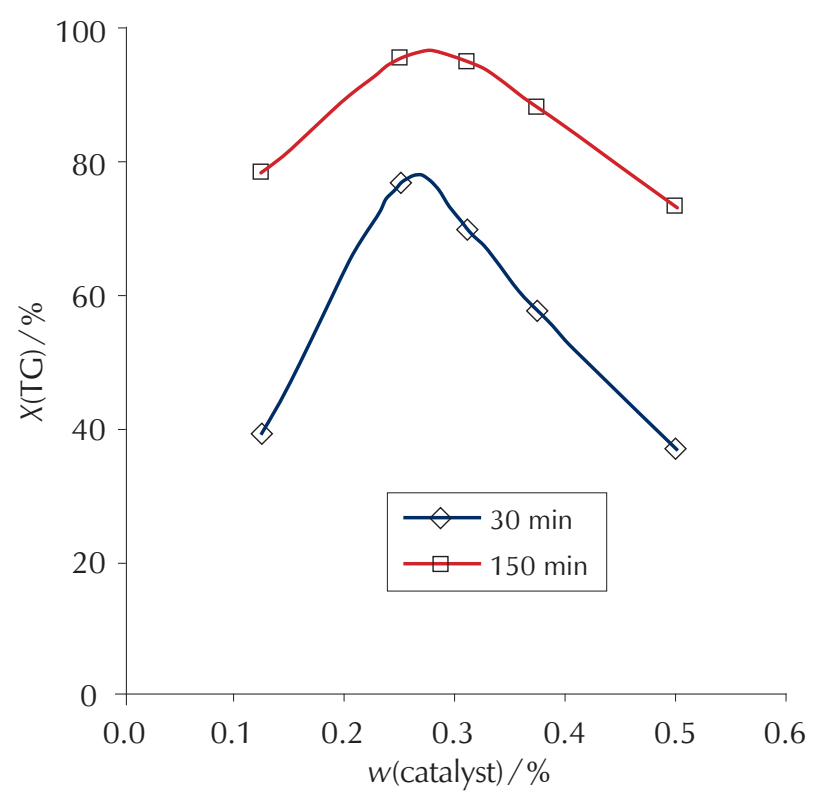

Fig. 2 -Dependence of TG conversion on the zinc oxide content for the transesterification of sunflower oil triglycerides. (Temperature $75^{\circ} \mathrm{C}$, molar ratio of ethanol: TG $5.7: 1$ ).

The most probable reason for the decrease in TG conversion with increasing catalyst content is the reduction of the catalyst active content due to its aggregation. ${ }^{13}$

Since one of the disadvantages of using homogeneous catalysts is the requirement for water absence in raw ma- terials, ${ }^{1}$ we studied the transesterification of sunflower oil triglycerides with ethanol in the presence of zinc oxide and mass fraction of water of 5 and $10 \%$ (Table 3).

At mass fraction of water in ethanol of $5 \%$, the triglycerides conversion after 150 min was $98.5 \%$. This indicates the possibility of using zinc oxide as a catalyst for the transesterification of raw materials containing water. Further increase in mass fraction of water to $10 \%$ led to some decrease in the triglycerides conversion after 150 min, but even in this case, it was $94.8 \%$. The use of ultrasonic waves in the transesterification process led to the decrease in the initial reaction rate and conversion of triglycerides (Table 3).

The effect of the oil type on the process was studied by using sunflower, rapeseed, and linseed oils. It is characteristic that rapeseed and linseed oils, as distinct from sunflower oil, contain FFA, as evidenced by the acid numbers defined for these oils (6.1 and $3.1 \mathrm{mg} \mathrm{KOH} / \mathrm{g}$, respectively). It was found that when using rapeseed oil, the zinc, and nickel(II) oxides provided a sufficiently high conversion of triglycerides after $150 \mathrm{~min}$ (Table 4). The initial acid number of sunflower oil was $0.2 \mathrm{mg} \mathrm{KOH} / \mathrm{g}$, therefore, its change during the reaction was not controlled.

When linseed oil was used, the triglycerides conversion after $150 \mathrm{~min}$ in the presence of nickel(II) oxide was only $88.3 \%$, whereas with the use of zinc oxide, a conversion of $93.0 \%$ was achieved. It was established that along with the transesterification reaction, there was an esterification reaction of FFA present in the rapeseed and linseed oils. The conversion of acids, calculated by changes in the acid number of the reaction mixture at the beginning and end of the reaction, was $5.7-14.3 \%$.

Table 3 - Effect of water content in ethanol on the indicators of transesterification process of sunflower oil triglycerides with ethanol. (Temperature $75^{\circ} \mathrm{C}$, zinc oxide catalyst, catalyst content $0.25 \mathrm{wt} \%$, molar ratio of ethanol : TG $5.7: 1$ ).

\begin{tabular}{c|c|c|c|c}
\hline \multirow{2}{*}{ Ultrasound } & $\begin{array}{c}\text { Mass fraction of water } \\
\text { in ethanol } / \%\end{array}$ & \multicolumn{2}{|c|}{ TG conversion $/ \%$} & Initial reaction rate $/ r \times 10^{4}, \mathrm{~mol} /(\mathrm{L} \times \mathrm{s})$ \\
\cline { 3 - 5 }+ & 5 & $79 \mathrm{~min}$ & $150 \mathrm{~min}$ & 3.54 \\
\hline- & 5 & 84.6 & 91.4 & 3.77 \\
\hline+ & 10 & 75.2 & 88.5 & 3.35 \\
\hline- & 10 & 83.7 & 94.8 & 3.72 \\
\hline
\end{tabular}

Table 4 - Effect of oil type on the conversion of triglycerides and FFA of vegetable oils. (Temperature $75{ }^{\circ} \mathrm{C}$, catalyst content 0.25 wt $\%$, molar ratio of ethanol: TG $5.7: 1$ ).

\begin{tabular}{|c|c|c|c|c|}
\hline \multirow{2}{*}{ Oil } & \multicolumn{2}{|c|}{ TG conversion / \% } & \multirow{2}{*}{ Initial reaction rate $/ r \times 10^{4}, \mathrm{~mol} /(\mathrm{L} \times \mathrm{s})$} & \multirow{2}{*}{ Acids conversion $/ \%$} \\
\hline & $30 \mathrm{~min}$ & $150 \min$ & & \\
\hline \multicolumn{5}{|c|}{$\mathrm{ZnO}$} \\
\hline sunflower & 85.0 & 99.1 & 3.78 & - \\
\hline rapeseed & 83.7 & 96.7 & 3.72 & 14.0 \\
\hline linseed & 76.2 & 93.0 & 3.39 & 14.3 \\
\hline \multicolumn{5}{|c|}{$\mathrm{NiO}$} \\
\hline rapeseed & 74.4 & 93.0 & 3.31 & 5.7 \\
\hline linseed & 69.7 & 88.3 & 3.10 & 14.0 \\
\hline
\end{tabular}




\section{Conclusion}

Studies have shown high catalytic activity of fine metal oxides as catalysts for transesterification of vegetable oils triglycerides with ethanol. Zinc and nickel(II) oxides were found to be the most active catalysts among the studied metal oxides. An optimum mass fraction of the mentioned catalysts (0.25-0.30 \%) was determined. It was established that the increase in ethanol : triglycerides molar ratio resulted in almost complete conversion of sunflower oil triglycerides. When using zinc oxide as catalyst, raw materials containing up to $5-10 \%$ of water may be applied for the transesterification reaction. It was also found that in the presence of zinc and nickel(II) oxides, along with the transesterification reaction of triglycerides, an esterification reaction of FFA present in the vegetable raw material takes place.

\section{List of abbreviations}

FFA - free fatty acid

TG - triglyceride

\section{References \\ Literatura}

1. J. Van Gerpen, Biodiesel processing and production, Fuel Process. Technol. 86 (2005) 1097-1107, doi: https://doi. org/10.1016/j.fuproc.2004.11.005.

2. D. Y. Leung, X. Wu, H. M. Leung, A review on biodiesel production using catalyzed transesterification, Appl. Energ. 87 (2010) 1083-1095, doi: https://doi.org/10.1016/j.apenergy.2009.10.006.

3. S. Yan, C. DiMaggio, S. Mohan, M. Kim, S. O. Salley, Advancements in heterogeneous catalysis for biodiesel synthesis, Topics Catal. 53 (11-12) (2010) 721-736, doi: https://doi. org/10.1007/s11244-010-9460-5.

4. O. Ilgen, A. Akin, Development of Alumina Supported Alkaline Catalysts Used for Biodiesel Production", Turkish J. Chem. 33 (2009) 281-287, https://doi.org/10.3906/kim0809-29.

5. R. Irmawati, I. Shafizah, A. Nur Sharina, H. Abbastabar Ahangar, Y. H. Taufiq-Yap, Transesterification of Palm Oil by Using Silica Loaded Potassium Carbonate $\left(\mathrm{K}_{2} \mathrm{CO}_{3} / \mathrm{SiO}_{2}\right)$ Catalysts to Produce Fatty Acid Methyl Esters (FAME), Energ. Power 4 (1) (2014) 7-15, doi: https://doi.org/10.5923/j. ep.20140401.02.
6. H. Nayebzadeh, N. Saghatoleslami, M. Haghighi, M. Tabasizadeh, Influence of fuel type on microwave-enhanced fabrication of $\mathrm{KOH} / \mathrm{Ca}_{12} \mathrm{Al}_{14} \mathrm{O}_{33}$ nanocatalyst for biodiesel production via microwave heating, J. Taiwan Inst. Chem. Eng. 75 (2017) 148-155, doi: https://doi.org/10.1016/j. jtice.2017.03.018.

7. C. MacLeod, A. Harvey, A. Lee, K. Wilson, Evaluation of the activity and stability of alkali-doped metal oxide catalysts for application to an intensified method of biodiesel production, Chem. Eng. J. 135 (2008). 63-70, doi: https://doi. org/10.1016/j.cej.2007.04.014.

8. S. Asif, L. F. Chuah, J. J. Klemeš, M. Ahmad, M. M. Akbar, K.T. Lee, A. Fatima, Cleaner production of methyl ester from non-edible feedstock by ultrasonic-assisted cavitation system, J. Clean. Prod. 161 (2017) 1360-1373, doi: https://doi. org/10.1016/j.jclepro.2017.02.081.

9. E. Martinez-Guerra, G. V. Gude, Transesterification of used vegetable oil catalyzed by barium oxide under simultaneous microwave and ultrasound irradiations, Energ. Convers. Manag. 88 (2014) 633-640, doi: https://doi.org/10.1016/j. enconman.2014.08.060.

10. Y. Xiang, L. Wang, Y. Jiao, Ultrasound strengthened biodiesel production from waste cooking oil using modified coal fly ash as catalyst, J. Environ. Chem. Eng. 4 (1) (2016) 818-824, doi: https://doi.org/10.1016/j.jece.2015.12.031.

11. B. Vafakish, M. Barari, Biodiesel Production by Transesterification of Tallow Fat Using Heterogenous Catalysis, Kem. Ind. 66 (1-2) (2017) 47-52, doi: https://doi.org/10.15255/ KUI.2016.002.

12. Yu. Melnyk, S. Melnyk, Z. Palyukh, B. Dzinyak, Research into transesterification of triglycerides by aliphatic alcohols $\mathrm{C} 2-\mathrm{C} 4$ in the presence of ionites, Eastern-European J. Enterp. Technol. 1/6(91) (2018) 10-16, doi: https://doi. org/10.15587/1729-4061.2018.122938.

13. Yu. Melnyk, S. Melnyk, R. Starchevskyi, Transesterification of sunflower oil triglycerides by 1-butanol in the presence of d-metal oxides, Voprosy khimii i khimicheskoi tekhnologii 4 (2019) 95-100, doi: https://doi.org/10.32434/0321-40952019-125-4-95-100.

14. Yu. Melnyk, R. Starchevskyi, S. Melnyk, Transesterification of triglycerides by ethanol in the presence of metal oxides, Bulletin of NTU "KhPl". Series: New solutions in modern technologies 5 (1330) (2019) 132-138, doi: https://doi. org/10.20998/2413-4295.2019.05.17.

15. Methodology for Lipids. Estimation of free fatty acids. [online] Available at: http://www.biocyclopedia.com/index/ plant_protocols/lipids/Estimation_of_free_fatty_acids.php [Accessed: 30 October 2019]. 


\section{SAŽETAK}

\section{Tehnološki aspekti transseterifikacije biljnih ulja etanolom u prisutnosti metalnih oksida \\ Yuriy Melnyk, Roman Starchevskyi i Stepan Melnyk}

Ispitana je transseterifikacija biljnog ulja etanolom u prisustvu sitnih čestica metalnih oksida kao katalizatora. Pokazalo se da najveću katalitičku aktivnost imaju cinkovi i nikl(II) oksidi. U njihovoj prisutnosti, konverzija triglicerida suncokretova ulja nakon 150 min dostigla je 95,3 odnosno $94,2 \%$. Otkriveno je da je optimalni maseni udio katalizatora cinkova oksida 0,25 - 0,31\%. U prisutnosti cinkova oksida, s udjelom vode u etanolu od 5 i 10 mas.\%, konverzija triglicerida iznosila je 98,5 odnosno $94,8 \%$.

\section{Ključne riječi}

Transeterifikacija, trigliceridi, metalni oksidi, etanol

Department of Organic Products Technology,

Izvorni znanstveni rad Lviv Polytechnic National University

S. Bandery str., 12

Prispjelo 9. prosinca 2019.

Lviv, 79013 Ukrajina 